УДК 355.1-053.18»364»: 94(100)»1939/1945»

DOI: 10.33099/2707-1383-2020-37-3-55-69

Іванчук В.А., провідний науковий співробітник науково-дослідного иентру воєнної історії Наиіонального університету оборони України імені Івана Черняховського (м. Киї, Украӥнав) ORCID: https://orcid.org/0000-0003-1279-8892 Новікова В.Г., старший науковий співробітник науково-дослідного ичентру воєнної історії Національний університет оборони Украӥни імені Івана Черняховського (м. Київ, Україна) ORCID: https://orcid.org/0000-0002-6876-9508

\title{
НІМЕЦЬКО-РАДЯНСЬКА ВІЙНА 1941-1945 рр.: БЕЗПОВОРОТНІ ЛЮДСЬКІ ВТРАТИ УКРАЇНИ
}

У повоєнний період в радянській історіографії з ідеологічних причин постійно приховувались дійсні масштаби людських втрат Радянського Союзу у Другій світовій війні. В той же час, необхідно віддати належне, офіиійна статистика підкреслювала приблизну рівність представниичтва всіх національностей у складі Червоної Армії періоду 1941-1945 років у відсотковому співвідношенні до загальної чисельності населення республік. Цей принщип дотримувався з тих же ідеологічних причин. У статті доводиться, щчо з розпадом Радянського Союзу та спрощенням доступу до архівів, об'єктивності та історичної справедливості в нових дослідженнях майже не добавилось. Навпаки, на догоду настроям відтворювачів імперії, в сучасній Російській Федерачії запанувала коничепиія про те, щзо «головну ношу війни виніс на собі російський народ».

Ключові слова: Друга світова війна, німецько-радянська війна, безповоротні втрати, статистичні дані, мобілізація, Червона Армія (РСЧА), СРСР, Україна, Міністерство оборони Російської Федеращії.

Постановка проблеми. Основним критерієм, за яким оцінюється масштабність та інтенсивність ведення будь-якого воєнного конфлікту — це кількість задіяних в ньому людських, матеріальних ресурсів i, відповідно, їхні безповоротні втрати. Звичайно, що найстрашніша плата, яку бере війна — це людські життя. На відміну від попередніх війн, Друга світова відзначилася масштабними людськими втратами, які, за різними оцінками, сягають від 50 до 80 мільйонів чоловік. Найбільших людських втрат 
у Другій світовій війні зазнав Радянський Союз та Німеччина і левова частка їх приходиться на німецько-радянську війну 1941-1945 років. Загально визнано, що Україна стала найбільш постраждалою республікою [28].

Аналіз останніх досліджень і публікацій. Питання людських втрат України під час німецько-радянської війни до 1990-х років взагалі не досліджувалося. Місце й роль України у Другій світовій війні в радянський період традиційно розглядалися крізь призму «Великої Вітчизняної війни СРСР» проти гітлерівської Нiмеччини та іiі союзників. Тематика людських втрат була завжди закритою, оприлюднювались лише загальні цифри в мільйонах. Весь радянський наратив у цій тематичній ніші, акумульований у підсумкових багатотомних виданнях, формувався в теоретичному руслі комуністичної ідеології [7, 8, 29].

Після 1991 року питання втрат, як і проблематика щодо радянсько-німецького збройного зіткнення взагалі, постало перед військовими істориками в буквальному сенсі слова «не ораним полем». В результаті полеміки, яка розгорілася в умовах кризи радянської влади та не вщухає і по сьогодні, чимало «каміння» летить в бік Російської Федерації, як «правонаступника СРСР», а точніше його «Перемоги у Великій Вітчизняній війні». I тоді, на захист стає Міністерство оборони РФ. Так, у 2009 році у московському видавництві «Издательский дом «Вече» вийшла книга «Великая Отечественная без грифа секретности. Книга потерь». У ній використані раніш не доступні документи Генерального штабу і головних штабів видів ЗС, МВС, ФСБ, прикордонних військ та інших структур колишнього СРСР. Крім загальних підходів у виданні наведені втрати військовослужбовців РСЧА за національністю та загальні людські втрати суб'єктів і регіонів СРСР, завдяки цьому підходу ми маємо цифрові матеріали по Україні. Ця статистика опрацьована комісією під головуванням Г. Кривошеєва, використовувалась у багатьох російських проектах. Зокрема в роботах Л. Рибаковського [25] та в таких узагальнюючих працях як «Памяти павших» [20] та багатьох інших.

Після розпаду СРСР та 3 відновленням національної державності розпочався пошук українськоцентричної версії Другої світової війни, спрямованої на реконструкцію радянського міфу «Великої Вітчизняної». Проблематика людських втрат постала в центрі наукової думки і громадської діяльності в період роботи державної комісії по опрацюванню Книги Пам'яті України. В багатотомних виданнях втрати були проаналізовані за кожну область. Все це підсумовано в заключному томі Книги Пам'яті України — «Безсмертя» [1]. Ця інформація використана в новітніх працях українських науковців 
М.В. Коваля, О.С. Лисенка, С.В. Сидорова, В.І. Горєлова, В.М. Грицюка, Л.В. Рибченко та ін. [10, 14, 27, 5, 23] Зарубіжні вчені свій науковий інтерес, пов'язаний з Україною, обмежують переважно окремими епізодами 3 перебігу бойових дій, проблемами примусової праці, Голокосту, терору окупаційної доби, військового полону, колабораціонізму та ін. [17, 11, 12]

Безповоротні людські військові втрати України під час німецько-радянської війни обліковані на основі вітчизняної документальної бази, яка стала доступною лише в останні роки, після формування в Національному музеї історії України у Другій світовій війні Документального фонду 3 обліку людських військових втрат України у Другій світовій війні. Вони оприлюднені в роботах Л. Рибченко. [24, с. 5, 6] Однак слід констатувати, що сучасні вітчизняні автори концентруються саме на дослідженні військових втрат, а загально людські втрати, внесок України в боротьбу антигітлерівської коаліції належним чином ще не проаналізовано.

Мета статті: узагальнити сучасні наукові погляди та окреслити проблему визначення людських втрат України у Другій світовій війні.

Виклад основного матеріалу. Вперше офіційно втрати СРСР у Другій світовій війні було заявлено I. Сталіним у лютому 1946 року 7 мільйонів чоловік. [2, с. 7] У 1960ті роки М. Хрущов оголосив вже іншу цифру — «понад 20 мільйонів людей», яка широко цитується у всьому світі і по сьогоднішній день. [2, с. 7]

Після розпаду СРСР у його «правонаступника» - Росії, крім приховування дійсних масштабів людських втрат, з'явилось ще одне завдання - применшити внесок у Перемогу над гітлерівською Нiмеччиною всіх інших суб'єктів Радянського Союзу, крім Росії. Особливо це стосується України. Адже, на iï території бойові дії проходили протягом 1941-1944 років, при цьому безпосередньо активні фази налічують близько 30 місяців, що становить $75 \%$ часу тривалості всієї війни [27, с. 485]. Тому їм вкрай необхідно приховати той факт, що в більшій мірі саме український народ опинився у кривавих жерновах непримиренної боротьби між нацизмом та більшовизмом.

За даними Міністерства оборони РФ щодо безповоротних втрат військовослужбовців в роки війни за «національною відзнакою», українців - 1,4 млн. чоловік (16\% від загиблих в РСЧА) [3, с. 52; 18, с. 545]. На території України під час окупації німецькими військами загинуло 3,3 млн. чоловік мирного населення, вивезено на роботи до Німеччини 2,4 млн. чоловік. [3, с. 46, 47] Шляхом звичайного арифметичного рахування виходимо на цифру в 7 мільйонів безповоротно втрачених людей.

Насамперед, позначимо основну глобальну нестиковку: станом на 
22 червня 1941 року населення України складало 41,7 мільйона чоловік, в 1945 році - 27,4 мільйона чоловік. Різниця в 14,3 мільйона! [14, с. 8 ; 22]

Почнемо з безповоротних військових втрат, адже облік саме цієї категорії людей під час війни має проводитися ретельно. Тому виникають питання:

По-перше: за даними МО РФ за роки радянсько-німецької війни до Червоної Армії було мобілізовано 29,5 млн. громадян СРСР, з яких понад 21 млн. 3 території Російської Федерації [3, с. 36, 37]. Відповідно цих даних, на всі інші суб'єкти Радянського Союзу припадає близько 8 млн. мобілізованих.

Однак, за результатами останніх досліджень вже в другій половині 1941 року з території України було відправлено до військових частин 3,2 млн. громадян, в період з лютого 1943 року до жовтня 1944 року 3,7 млн. [27, с. 474]. Мобілізації тривали і в 1945 році, до самого завершення війни. Зазначимо, за офіційними даними ЦАМО РФ і ЦДАГО України тільки з України через РСЧА пройшло щонайменше 7 млн. чоловік [18, с. 547].

По-друге: Близько 3,5 млн. мешканців України на початку війни було евакуйовано до східних регіонів СРСР і там поставлено на військовий облік [14, с. 24]. Скільки з них у подальшому було мобілізовано і загинуло на фронтах? Питання залишається відкритим.
По-третє: Російські військові історики застосовують досить зручну для маніпуляцій систему підрахунку втрат. В цій системі не викликає питань лише перший підпункт — «Убуло в ході війни» (всього з числа призваних) - 21,6 млн. чол., 3 них:

безповоротні втрати військовослужбовців списочного складу 11,4 млн. чол., (загинули, померли та розстріляні за вироками судів, пропало без вісті, потрапили в полон).

Фактичні безповоротні втрати військовослужбовців списочного складу (загинуло) $-8,7$ млн. чол. [3, с. 41] (саме 3 цієї кількості «українська доля» складає 16\%).

Тут звертає на себе увагу цікава деталь: у вищезгаданому довіднику подано і втрати Німеччини. Безповоротні втрати, чітко, конкретно, без ніяких «фактичних» - 11,8 млн. чол. [2, с. 366] (не нагадує безповоротні втрати списочного складу РСЧА?). В той же час, в інших історичних дослідженнях часто зустрічається цифра щодо кількості втрат вермахту та його союзників на Європейському театрі бойових дій - 8,6 млн. чол. [3, с. 13; 11, с. 556] (майже один в один як і фактичні безповоротні втрати списочного складу РСЧА!).

Що це - співпадіння, чи штучна підгонка, з метою видати за «у нас не більше»?

По-четверте: Якщо взяти надані МО РФ безповоротні втрати РСЧА під час загального відступу у 1941 році - 3,1 млн. чол. [3, с. 60; 
4, с. 15], то доля загиблих українців тільки в цей період має бути в межах 600 тис. чоловік.

Дослідники стверджують, що внаслідок втрати території України та відповідного мобресерсу, у 1942 році доля вихідців з України в армії різко впала з $20 \%$ [27, с. 371$]$ до $10 \%-11 \%$, і зберігалась такою до другої половини 1943 року [27, с. 386]. Але ж Червона армія в цей період пройшла ще через ряд військових катастроф, і втрати залишались величезними. Так, протягом 1942 року СРСР зазнав безповоротних втрат у кількості 3,3 млн. військовослужбовців $[3$, с. 60]. Навіть 3 урахуванням значного зменшення долі українців у діючій армії, кількість втрат серед них за цей рік має бути близько 300 тис. чоловік. У 1945 році безповоротно втрачено ще 0,8 млн. чол. [3, с. 60], 3 них частка мешканців України може сягати понад 0,2 млн.

Щодо України, то найбільш втрат військ зазнали саме на їі теренах. На підтвердження цьому існує достатня кількість фактів та обставин:

1) Із січня 1943 року до жовтня 1944 року Червона армія на українських теренах здійснила стратегічних 10 наступальних і 1 оборонну операцій та фронтових 7 наступальних і 1 оборонну операцій [27, с. 477, 478]. Однак, внаслідок невірної оцінки обстановки з боку командування та неналежного забезпечення і підготовки військ, під час проведення близько половини наступальних i оборонних операцій поставленої мети досягти не вдалося [27, с. 487]. Як наслідок, це завжди призводило до незапланованих та невиправданих втрат, особливо серед особового складу.

Прикладом цьому є штурмування легендарної Савур-Могили в серпні 1943 року під час боїв за утримання плацдарму на річці Міус на Донбаci. 329 по 31 серпня Червона армія безуспішно здійснювала безперервні лобові атаки на висоту, в яких безпосередньо були задіяні 291-ий, 293-ий та 295-ий стрілецькі полки 96-ої гвардійської стрілецької дивізії за підтримки ще двох стрілецьких полків 271-ої стрілецької дивізії. За три дні штурму ці частини втратили до половини особового складу (від бойового складу на момент початку атак). Нiмецькі підрозділи лише під загрозою оточення самі залишили свої позиції (командування вермахту завжди берегло свій найцінніший скарб - людей) [26]. Однак, командування 96-ої гвардійської стрілецької дивізії браво рапортувало про зайняття пустих позицій як результат вдалого наступу 3 послідуючим переслідуванням противника [15].

Через декілька днів до висоти зігнали місцевих мешканців, які три дні збирали, складали в штабелі та палили трупи. Дані на загиблих сержантського та рядового складу Червоної армії при цьому не встановлювались, місце поховання залишків 
після кремації не відмічалось і нині не відомо [26].

Через 71 рік, влітку 2014 року Савур-Могила знову стала місцем протистояння. Тільки на цей раз між підрозділами Збройних Сил України, українськими добровольцями та російсько-терористичними військами. В період 37 по 24 серпня, під безперервними обстрілами та атаками противника, з обмеженою кількістю боєприпасів, продовольства, а головне - за відсутністю води (а в ті дні стояла спека!), висоту утримували декілька десятків українських бійців на чолі з полковником Ігорем Гордійчуком (група «Сумрака»). Лише після переходу російськими регулярними військами кордону України та повного охоплення ними Савур-Могили, захисники висоти отримали відповідний наказ та залишили свої позиції [6].

I хоча Савур-Могила тимчасово була захоплена російськими окупантами, бої за неї залишаться символом мужності українських військових та добровольців. Живих і загинувших.

2) В ході безперервних наступальних боїв частини Червоної армії несли тяжкі втрати та постійно відчували некомплект до 50-60\% [16, с. 201]. Ставка ВГК навіть у розпал стратегічних операцій, у кращому випадку, посилювала резервами війська від $15 \%$ до $64 \%$ [27, с. 485$]$.

При цьому для командування військами завдань ніхто не відміняв, a для їх виконання вони постійно потребували резервів, перш за все людей. I якщо не присилала Ставка, то командири їх брали самі. Спеціально створені «польові військкомати» в кожному місті, містечку та селі, не відбираючи, ставили до строю всіх чоловіків від 17 до 50 років. Це були юнаки, які підросли за роки окупації, відпущені додому військовополонені та ті, хто через певні обставини опинилися на зайнятій ворогом територіiі.

Затавроване перебуванням на окупованій території нове поповнення, як правило, не брали на облік особового складу та відразу направляли змивати свою «провину» кров'ю до «очищення» на передову, в піхоту. В лобових атаках, у цивільному одязі, погано озброєні та навчені, вони майже не мали шансів повернутися живими, а загиблими їх мали зараховувати не військові частини, а місцеві органи влади і військкомати відповідно до заяв родин (можна собі тільки уявити, як ці заяви подавались, приймались та розглядались!).

Навіть німецькі військовослужбовці у своїх спогадах називають їх «чорними батальйонами» (за цивільну форму одягу), або Beutesoldaten «трофейні солдати» (за відповідне відношення до них з боку радянського командування).

3) Тільки за офіційними даними у 1943 та 1944 роках на Україні було мобілізовано до війська близь- 
ко 4 млн. чол. місцевого населення. Однак, облік залучених до Червоної армії здійснювався різними органами - військовими, військово-адміністративними та партійними, що значно ускладнювало цей процес. Нерідкістю були випадки, коли в 3'єднаннях та частинах лише половина наявного особового складу стояла на обліку.

Саме у 1943 році у військово-адміністративному апараті Червоної армії відбувалася зміна центральних облікових органів та порядку зарахування полеглого рядового, сержантського складу й офіцерів. Ці зміни не сприяли покращенню й до того незадовільної роботи з обліку загиблих у війську. Централізоване зарахування проводилося у двох військово-адміністративних центрах - Головному управлінні кадрів Народного комісаріату оборони та Управлінні 3 обліку втрат, підпорядкованому начальнику Тилу Червоної армії. Започатковані зміни спричинили певний хаос у війську. Серед звітних документів часто зустрічаються нарікання про втрату списків загиблих або направлення їх не за призначенням. У межах фронтів недооблік загиблих нараховувався тисячами [23].

4) Внаслідок мобілізації українського населення у 1943-44 роках, кількість його в лавах радянських військ сягнула 60\% (у з'єднаннях 1-го Українського фронту — до 80\%) [5, с. 37]. Відповідно збільшилася й кількість втрат вихідців з України в цих боях, остаточна цифра яких залишається нез'ясованою.

Прикладом цього є 3 гвардійська танкова армія 1 Українського фронту, яка перед початком Сумсько-Прилукської наступальної операції в кінці серпня 1943 року мала у своєму складі 38,3 тис. чол. В грудні 1943 року - перед початком Житомирсько-Бердичівської наступальної операції - бойовий склад армії після наступальних боїв значно скоротився. Навіть після отримання поповнення вона нараховувала 9573 чол. А от на початок Львовсько-Сандомирської наступальної операції (15 липня 1944 року) - вже 41,8 тис. чол. [16, с. 204].

За статистикою безповоротні втрати 1, 2, 3 та 4-го Українських фронтів в кампаніях 1943-44 років складали близько 1,5 млн. чол. [3, с. $219,224,226,229]$. Але, враховуючи вищезазначені особливості «офіційних даних», маємо підстави вважати, що ці втрати сягали понад 2,5 млн. чол. Відповідно, «українська» доля в них може бути близько 1,5 млн. чол.

5) Радянська (російська) статистика свідомо не враховує втрати своїх громадян, які воювали в інших військових формуваннях. Українці також не $\epsilon$ виключенням. Але ми маємо визнати, що ця війна набула і громадянського протистояння. Його трагедія полягає в тому, що більшість українців, будь вони одягнуті у радянські гімнастерки, мундири 
вермахту або повстанські однострої, однаково любили Україну і свідомо воювали за неї. Мета у них була однакова, а от вибір шляху їі досягнення був різний.

Так, під час війни поклали свої голови 40-45 тис. радянських підпільників та близько 60 тис. українських партизанів [14, с. 26]. Не менше 150 тис. осіб становили втрати членів ОУН та вояків УПА [9, с. 390]; тільки у складі дивізії СС «Галичина» за офіційними даними загинуло 16 тис. українців, а у складі інших збройних формувань, що воювали на боці Німеччини чи союзників СРСР — остаточно невідомо [19].

6) На даний час немає навіть приблизної кількості втрат мирного населення України внаслідок активних бойових дій із застосуванням тактики «випаленої землі» в Україні під час відступу у 1941 та під час наступу РСЧА у 1943-44 роках (хоча під час німецької окупації втрати підраховано).

Також, за роки війни добровільні та примусові міждержавні міграції охопили близько 1,5 млн. мешканців України [14, с. 27].

Таким чином, аналіз статистики свідчить про те, що лише військові втрати українців з усіх боків протистояння налічують близько 4 млн. чол., втрати мирного населення (евакуація, окупація, «визволення», міжетнічні конфлікти, померлі, голокост, добровільні та примусові міграції) - понад 10 млн. чол. [22].
Однак, ми мусимо констатувати, що ці обрахунки дуже наближені, при чому з важелем у бік зменшення.

Зрештою, зрозуміло: справжні втрати і України, і Радянського Союзу в цілому у Другій світовій війні ніколи вже остаточно не будуть з'ясовані - надто багато часу минуло відтоді і товстий шар різного роду напластувань огортає цю проблему. А головне - i досі існують зацікавлені «сильні світу цього», яким вкрай невигідна історична правда щодо бодай приблизної «ціни» за Перемогу.

Показово, що у 2020 році (75-та річниця закінчення війни) Національним музеєм історії України у Другій світовій війні розпочато унікальний проект - перший приклад упорядкування розпорошених «похоронок» та облікових документів на пострадянських теренах та створення всеукраїнського пошукового порталу загиблих комбатантів різних військових формувань періоду Другої світової війни [21].

Висновки. Найбільшою цінністю в світі є людське життя. Смерть навіть однієї людини тягне за собою загибель цілого, хай навіть маленького світу. Адже за насильницькою втратою лише одного людського життя стоять невтішне горе рідних та близьких, сирітство або взагалі ненародження дітей. А під час війни — це ще й, як правило, у розквіті життєвих сил.

Друга світова війна стала трагедією планетарного масштабу. Між 
1939 та 1945 роками 110 мільйонів молодих людей від 17 до 20 років 35ти національностей в 61 країні одягли військову форму різних армій. 27 мільйонів 3 них ніколи не повернулись додому [2, с. 5]. В СРСР доля втрат військовослужбовців віком до 35 років складає $74 \%$ [3, с. 51]. Тому, саме людські втрати $\epsilon$ найболючішими і найтрагічнішими, особливо, коли вони сягають мільйонів та 3 часом перетворюються на звичайну суху статистику. Слід визнати, що і людські втрати України неможливо обчислити більш - менш точно. Авторитетні видання стверджують, що втрати України у німецько-радянській війні становлять від 7 до 8 млн. осіб. [30]. Люди гинули на фронтах і в партизанських загонах, у таборах для військовополонених і в єврейських гетто, в окупованих містах, які не постачалися продовольством, і в непосильній рабській праці в Німеччині.

Жоден 3 народів, усвідомлюючи свою гідність, не потребує його штучного звеличення за рахунок інших, але не потерпить і приниження. Цинічне маніпулювання статистичними даними мільйонних людських втрат з метою задоволення своїх геополітичних (імперських) амбіцій, як це робить вище державне керівництво Російської Федерації, принижує пам'ять загиблих, а головне - створює передумови для конфліктів у подальшому.

\section{СПИСОК ВИКОРИСТАНИХ ДЖЕРЕЛ І ЛІТЕРАТУРИ}

1. Безсмертя: Книга Пам’яті України 1941-1945 pp. - Київ: Пошуково-видавниче агенство «Книга Пам’яті України», 2000. — 944 с.

2. Буровський А. Не вторая мировая, а Великая Гражданская! Запретная правда о войне. - М: «ЯУЗА-ПРЕС», 2012. - 509 с.

3. Великая Отечественная без грифа секретности. Книга потерь / Кривошеєв Г.Ф., Андронников В.М., Буриков П.Д., Гуркин В.В. - М: Издательский дом «Вече», 2010. $382 \mathrm{c}$.

4. Гареев М.А. Факторы, определившие потери в Великой Отечественной войне // Людские потери СССР в период второй мировой войны (сборник статей). Российская Академия наук (отделение истории), Институт российской истории Российской Академии наук, Научный совет Российской Академии наук по исторической демографии и исторической географии, Государственная архивная служба Российской федерации. - СанктПетербург: «Санкт-Петербург», 1995. - С. 13-17.

5. Горєлов B.I., Клименко В.С. Україна у Другій світовій війні: людський і матеріальний чинник перемоги над нацизмом // Воєнно-історичний вісник: збірник наукових 
праць Національного університету оборони України імені Івана Черняховського. - К.: «Компринт», 2017. Вип. 1(23). - С. 34-39.

6. Жирохов М. Схватка за Саур-Могилу // Третий материал ЛІГА.net из цикла публикаций о российско-украинской войне. [Електронний ресурс]. Режим доступу: https:/project.liga. net/projects/saur_mogila/

7. История Великой Отечественной войны Советского Союза 1941-1945: В 6т. /Пред. глав. ред. ком. П.Н. Поспелов. - Москва, 1960-1965.

8. История второй мировой войны 1939-1945: В 12 т. / Пред. ред. ком. А.А. Гречко. Москва, 1973-1982.

9. Історія українського війська / М. Відейко, А. Галушка, В. Лободаєв, М. Майоров, Я. Примаченко, А. Руккас, С. Синиця, О. Сокирко, А. Харук, Б. Черкас; керівник проекту К. Галушко; загальний редактор В. Павлов. - Харків: «Клуб сімейного дозвілля», 2016. — $415 \mathrm{c}$.

10. Коваль М.В. Україна в другій світовій і Великій Вітчизняній війнах (1939-1945). К., 1999. - 335 с..

11. Косик В. Україна і Німеччина у другій світовій війні. - Париж; Нью-Йорк; Л., 1993. - $658 \mathrm{c}$.

12. Косик В. Україна під час Другої світової війни 1938-1945 / Пер. $з$ фр. Р. Осадчука. К.; Париж; Нью-Йорк; Торонто; 1992. — 729 с.

13. Краснощок Ю. Документальний детектив «Диявольська гра». - К.: Видавничий центр «ДрУк», 2002. - 526 с.

14. Лисенко О.С. Демографічні втрати України у роки Другої світової війни / О. Є. Лисенко, О. Г. Перехрест // Архіви України, 2015, № 3. - С. 8-34. [Електронний ресурс]. Режим доступу: http://nbuv.gov.ua/UJRN/ay_2015_3_4.

15. Левин С.С. Наступают иловайцы // Твои освободители, Донбасс. Очерки, воспоминания / составитель Г. В. Тепляков. - 5-е, дополненное. - Донецк: «Донбасс», 1976. C. 195-198.

16. Мелехов А. Война моторов: танковая дубина Сталина, 100 часов на жизнь. Харьков «ФОЛИО» 2018. - 274 c.

17. Murray W., Millett A. A War To Be Won: Fighting the Second World War. - Academic Trade, 2001. - $736 \mathrm{p}$.

18. Муковський I.T., Лисенко О.С. Звитяга і жертовність. Українці на фронтах Другої світової війни. Пошуково-видавниче агентство «Книга пам’яті України» м. Київ. 1997. — $567 \mathrm{c}$.

19. Муковський І.Т. Втрати людські України в Другій Вітчизняній війні 1941-1945 pp. [Електронний ресурс]. «Наукова думка», 2003. Режим доступу: htt//www.history.org/ua/ ?termin=Vtraty_vijskovi.

20. Памяти павших, Великая Отечественная война (1941-1945) - М.: Большая Российская энциклопедия, 1995. - 336 с. 
21. Прес-реліз «Презентація пошукового порталу». Національний музей історії України у Другій світовій війні. Київ 2020. Режим доступу: martyrology.org.ua

22. ПроцикП. Україна. Другасвітова. Тількицифри [Електронний ресурс]. Українськаправда від 07.05.2010. Режим доступу: https://www.pravda.com.ua/rus/articles/2010/05/7/5017138/.

23. Рибченко Л. Персональний облік людських військових втрат Червоної армії у війні 3 нацистською Німеччиною [Електронний ресурс]. Режим доступу: http://www.historians. in.ua/index.php/en/zabuti-zertvy-viyny/1264-liudmyla-rybchenko-personalnyi-oblik-liudskykhviiskovykh-vtrat-chervonoi-armii-u-viini-z-na systskoiu-nimechchynoiu.

24. Рибченко Л.В. Людські втрати України в лавах РСЧА під час німецько-радянської війни // Воєнно-історичний вісник: Зб. наук. пр. Нац. ун-ту оборони України ім. І. Черняховського. - Вип. 2(36). - К., 2020. - С. 219-235.

25. Рыбаковский Л.Л. Великая Отечественная: людские потери России // Социологические исследования. - 2001. - 6. - С. 85-95.

26. Саур-Могила // Википедия [Електронний ресурс]. Режим доступу: https://ru.wikipedia. org/wiki/Саур-Могила

27. Стратегічні та фронтові операції на території України у 1943-944 роках / В.М. Грицюк, О.С. Лисенко, Р.І. Пилявець, С.В. Сидоров; відповідальний редактор О.С. Лисенко - К.: Національний університет оборони України імені Івана Черняховського, Інститут історії України НАН України, 2015. — 508 с.

28. Україна в лавах Об’єднаних націй: легітимізація та внесок у боротьбу з нацизмом і фашизмом у період Другої світової війни / В. Грицюк, О. Лисенко, А. Покотило // Український історичний журнал. - 2020. - Число 3. - С. 4-26. - Режим доступу: http://resource.history. org.ua/ publ/UIJ_2020_3_3

29. Украинская ССР в Великой Отечественной войне Советского Союза 1941-1945 гг.: В 3 т. /Редкол.: И.Д. Назаренко (пред.). - К., 1975.

30. Україна: утвердження незалежної держави (1991-2001) / Н.П. Барановська, В.Ф. Верстюк, С.В. Віднянський та ін.; під ред. В.М. Литвина. - К. Видавничий дім «Альтернативи», 2001. - С. 113.

\section{REFERENCES}

1. Bezsmertia: Knyha Pam'iati Ukrainy 1941-1945 [Book of Memory of Ukraine]. - Kyiv: Poshukovo — vydavnyche ahenstvo «Knyha Pam'iati Ukrainy» 2000. — 944 p.

2. Burovskij A. Ne vtoraya mirovaya, a Velikaya Grazhdanskaya! Zapretnaya pravda o vojne. [Not the Second World War, but the Great Civil War! The forbidden truth about the war] — M: «YAUZA-PRES», 2012. - 509 p.

3. Velikaya Otechestvennaya bez grifa sekretnosti. Kniga poter [The Great Patriotic without a stamp of secrecy. Book of losses] / Krivosheyev G.F., Andronnikov V.M., Burikov P.D., Gurkin V.V. — M: Izdatelskij dom "Veche", 2010. — 382p. 
4. Gareev M.A. Faktory, opredelivshie poteri v Velikoj Otechestvennoj vojne [Factors that determined losses in the Great Patriotic War] // Lyudskie poteri SSSR v period vtoroj mirovoj vojny (sbornik statej). Rossijskaya Akademiya nauk (otdelenie istorii), Institut rossijskoj istorii Rossijskoj Akademii nauk, Nauchnyj sovet Rossijskoj Akademii nauk po istoricheskoj demografii i istoricheskoj geografii, Gosudarstvennaya arhivnaya sluzhba Rossijskoj federacii. — SanktPeterburg: "Sankt-Peterburg”, 1995. — P. 13-17.

5. Horielov V.I., Klymenko V.S. Ukraina u Druhii svitovii viini: liudskyi i materialnyi chynnyk peremohy nad natsyzmom [Ukraine in the Second World War: the human and material factor of victory over Nazism] // Voienno-istorychnyi visnyk: zbirnyk naukovykh prats Natsionalnoho universytetu oborony Ukrainy imeni Ivana Cherniakhovskoho. — K.: "Komprynt", 2017. Vyp. 1(23). - P. 34-39.

6. Zhirohov M. Shvatka za Saur-Mogilu [Fight for Saur-Grave] // Tretij material LIGA.net iz cikla publikacij o rossijsko-ukrainskoj vojne. [Elektronnij resurs]. Rezhim dostupu:: https:// project.liga.net/projects/saur_mogila/.

7. Istoriya Velikoj Otechestvennoj vojny Sovetskogo Soyuza 1941-1945 [History of the Great Patriotic War of the Soviet Union in 1941-1945]: V 6t. / Pred. glav. red. kom. P.N. Pospelov. — Moskva, 1960-1965.

8. Istoriya vtoroj mirovoj vojny 1939-1945 [History of the Second World War in 1939-1945]: V 12t. / Pred. red. kom. A.A. Grechko. - Moskva, 1973-1982.

9. Istoriia ukrainskoho viiska [History of the Ukrainian army] / M. Videiko, A. Halushka, V. Lobodaiev, M. Maiorov, Ya. Prymachenko, A. Rukkas, Ye. Synytsia, O. Sokyrko, A. Kharuk, B. Cherkas; kerivnyk proektu K. Halushko; zahalnyi redaktor V. Pavlov. — Kharkiv: "Klub simeinoho dozvillia", 2016. - 415 p.

10. Koval M.V. Ukraina $\mathrm{v}$ druhii svitovii i Velykii Vitchyznianii viinakh [Ukraine in the Second World and the Great Patriotic Wars] (1939-1945). — K., 1999. $335 \mathrm{p}$.

11. Kosyk V. Ukraina i Nimechchyna u druhii svitovii viini. [Ukraine and Germany in the second World War] — Paryzh; Niu-York; L., 1993. - 658 p.

12. Kosyk V. Ukraina pid chas Druhoi svitovoi viiny 1938-1945 [Ukraine during the Second World War 1938-1945] / Per. z fr. R. Osadchuka. — K.; Paryzh; Niu-York; Toronto; 1992. — 729 p.

13. Krasnoshchok Yu. Dokumentalnyi detektyv "Dyiavolska hra". [Documentary detective Devil's game] - K.: Vydavnychyi tsentr "DrUk", 2002. — 526 p.

14. Lysenko O.Ie. Demohrafichni vtraty Ukrainy u roky Druhoi svitovoi viiny [Demographic losses of Ukraine during the Second World War] / O. Ye. Lysenko, O. H. Perekhrest // Arkhivy Ukrainy, 2015, № 3. - S. 8-34. [Elektronnyi resurs]. Rezhym dostupu: http://nbuv.gov.ua/UJRN/ ay_2015_3_4

15. Levin S.S. Nastupayut ilovajcy // Tvoi osvoboditeli, Donbass. [The Ilovais are coming // Your liberators, Donbass]. Ocherki, vospominaniya / sostavitel G. V. Teplyakov. — 5, dopolnennoe. — Doneck: "Donbass", 1976. — P. 195-198. 
16. Melehov A. Vojna motorov: tankovaya dubina Stalina, 100 chasov na zhizn. [War of motors: Stalin's tank club, 100 hours to live] Harkov "FOLIO" 2018. - 274 p.

17. Murray W., Millett A. A War To Be Won: Fighting the Second World War. - Academic Trade, 2001. - $736 \mathrm{p}$.

18. Mukovskyi I.T., Lysenko O.Ie. Zvytiaha i zhertovnist. Ukraintsi na frontakh Druhoi svitovoi viiny. [Victory and sacrifice. Ukrainians on the fronts of the World War II ] Poshukovo-vydavnyche ahentstvo "Knyha pamiati Ukrainy" m. Kyiv. 1997. — 567 p.

19. Mukovskyi I.T. Vtraty liudski Ukrainy v Druhii Vitchyznianii viini 1941 - 194 [Ukraine’s human losses in the Second Patriotic War 1941 - 1945] [Elektronnyi resurs]. "Naukova dumka", 2003. Rezhym dostupu: htt//www.history.org/ua/?termin=Vtraty_vijskovi.

20. Pamyati pavshih, Velikaya Otechestvennaya vojna (1941-1945) [To memory of fallen, the Great Patriotic War (1941-1945)] — M.: Bolshaya Rossijskaya enciklopediya, 1995. — 336 p.

21. Pres-reliz "Prezentatsiia poshukovoho portalu". [Presentation of the search portal]. Natsionalnyi muzei istorii Ukrainy u Druhii svitovii viini. Kyiv 2020. Rezhym dostupu: martyrology.org.ua

22. Protsyk P. Ukraina. Druha svitova. Tilky tsyfry [Ukraine. World War II. Only numbers] [Elektronnyi resurs]. Ukrainska pravda vid 07.05.2010. Rezhym dostupu:: https://www.pravda. com.ua/rus/articles/2010/05/7/5017138/.

23. Rybchenko L. Personalnyi oblik liudskykh viiskovykh vtrat Chervonoi armii u viini z natsystskoiu Nimechchynoiu [Personal accounting of human military losses of the Red Army in the war with Nazi German] [Elektronnyi resurs]. Rezhym dostupu: http://www.historians. in.ua/index.php/en/zabuti-zertvy-viyny/1264-liudmyla-rybchenko-personalnyi-oblik-liudskykhviiskovykh-vtrat-chervonoi-armii-u-viini-z-na systskoiu-nimechchynoiu.

24. Rybchenko L.V. Liudski vtraty Ukrainy v lavakh RSChA pid chas nimetsko-radianskoi viiny [Ukraine's human losses in the ranks of the RSCA during the German-Soviet war] // Voiennoistorychnyi visnyk: Zb. nauk. pr. Nats.un-tu oborony Ukrainy im. I. Cherniakhovskoho. Vyp. 2(36). - K., 2020. - P. 219-235.

25. Rybakovskij L.L. Velikaya Otechestvennaya: lyudskie poteri Rossii [The Great Patriotic War: human losses of Russia] // Sociologicheskie issledovaniya. — 2001. — 6. — P. 85-95.

26. Saur-Mogila // Vikipediya [Elektronnij resurs]. Rezhim dostupu: https://ru.wikipedia.org/ wiki/Saur-Mogila

27. Stratehichni ta frontovi operatsii na terytorii Ukrainy u 1943-1944 rokakh [Strategic and front operations on the territory of Ukraine in 1943-1944] / V.M. Hrytsiuk, O.Ie. Lysenko, R.I. Pyliavets, S.V. Sydorov; vidpovidalnyi redaktor O.Ie. Lysenko - K.: Natsionalnyi universytet oborony Ukrainy imeni Ivana Cherniakhovskoho, Instytut istorii Ukrainy NAN Ukrainy, 2015. — $508 \mathrm{p}$.

28. Ukraina v lavakh Obiednanykh natsii: legitymizatsiia ta vnesok u borotbu $\mathrm{z}$ natsyzmom $\mathrm{i}$ fashyzmom $\mathrm{u}$ period Druhoi svitovoi viiny [Ukraine in the ranks of the United Nations: legitimization and contribution to the fight against Nazism and fascism during the second World 
War] / V. Hrytsiuk, O. Lysenko, A. Pokotylo // Ukrainskyi istorychnyi zhurnal. — 2020. Chyslo 3. — P. 4-26. — Rezhym dostupu: http://resource.history.org.ua/ publ/UIJ_2020_3_3

29. Ukrainskaya SSR v Velikoj Otechestvennoj vojne Sovetskogo Soyuza 1941-1945 [Ukrainian SSR in the Great Patriotic War of the Soviet Union 1941-1945]: V 3 t. / Redkol.: I.D. Nazarenko (pred.). - K., 1975.

30. Ukraina: utverdzhennia nezalezhnoi derzhavy (1991-2001) [Ukraine: Approval of an Independent Power (1991-2001)] / N.P. Baranovska, V.F. Verstiuk, S.V. Vidnianskyi ta in.; pid red. V.M. Lytvyna. - K. Vydavnychyi dim "Alternatyvy", 2001. - P. 113.

Ivanchuk V.A., Leading Researcher of Research Center for Military History of National Defence University of Ukraine named after Ivan Cherniakhovskyi (Kyiv, Ukraine) ORCID: https://orcid.org/0000-0003-1279-8892

Novikova V.H., Researcher of Research Center for Military History of National Defence University of Ukraine named after Ivan Cherniakhovskyi (Kyiv, Ukraine) ORCID: https://orcid.org/0000-0002-6876-9508

\section{THE GERMAN-SOVIET WAR 1941-1945: THE IRREVOCABLE HUMAN LOSSES OF UKRAINE}

In the postwar period for ideological reasons the true extent of the Soviet Union's human casualties in World War II has always been hidden in the Soviet Union for ideological reasons. At the same time, we have to pay tribute to official statistics that emphasized equality of representation of all nationalities in the Red Army from 1941 to 1945, as a percentage of the total population of the USSR. This principle was followed for the same ideological reasons. However, in any case, Soviet historical science did not contain expressions of national sympathy or antipathy.

In the article the author proves that with the collapse of the Soviet Union and the ease of access to the archives, objectivity and historical justice were hardly added to these 
studies. Analysis of the statistics of the Defence Ministry of the Russian Federation about losses of the USSR in the Second World War testifies to a new concept: the main burden in this war was carried by the "Russians".

After the collapse of the USSR, in its "Successor" - Russia, apart from hiding the true scale of human loss, appeared one another task to diminish the contribution to the Victory over Hitler's Germany of all other subjects of the Soviet Union except Russia. This is especially addressed to Ukraine. Because of, in its territory fighting took place during 1941-1944, with that, the active phases are approximately 30 months, which is 75\% of the duration of the entire war.

The official statistics of Russian military historiography of the human losses of Ukraine in the German-Soviet War of 1941-1945 are artificially tuned to the political decisions and existing ideology of the ruling circles of the Russian Federation.

The real losses of both Ukraine and the Soviet Union as a whole in the Second World War will never be finally determined because of time that has passed since then. The main that there are still interested people who are extremely unprofitable with the historical truth about at least an approximate "price" for the Victory.

None of the people does not require artificial exaltation of dignity at the expense of others and will not suffer humiliation either. The cynical manipulation of the statistics of millions of human casualties in order to satisfy their geopolitical (imperial) ambitions diminishes the memory of the dead, and most importantly, creates the preconditions for future conflicts.

Keywords: World War II, Soviet-German War, irreversible losses, statistics, mobilization, Red Army (WPRA), USSR, Ukraine, Ministry of Defence of the Russian Federation. 